\title{
Measuring the efficiency of medical tourism industry in EU member states
}

\author{
Lorena Androutsou and Theodore Metaxas \\ Department of Economics, University of Thessaly, Volos, Greece
}

\begin{abstract}
Purpose - Under the Directive 2011/24/EU, medical tourism and cross-border health are interrelated terms regarding the freedom to move to get the most accessible medical treatment into EU Member State within the defined procedures for reimbursement. Little known empirically regarding the efficiency of the cross-border health/medical tourism industry. This study aims to measure its efficiency in Europe for the years 2010-2014, by using Data Envelopment Analysis (DEA).

Design/methodology/approach - Data obtained from OECD and the European Core Health Indicators (ECHI), which is collecting the data through Eurostat. Eurostat collects data on health-care activities and provides data on hospital discharges, including the hospital discharges of non-residents and these include hospital discharges of in-patients and day care patients. The analysis uses "DEA.P, 2.1 for windows" by Coelli (1996).
\end{abstract}

Findings - The results show that the Members States health systems were very efficient in handling nonresidents in-patients; however, when managing day cases/outpatients, the efficiency scores dropped.

Practical implications - The findings would have significant associations affecting intentions to revisit clinics and the destination country. In addition, will be useful to those seeking a better understanding of the cross-border health and medical tourism industry efficiency.

Originality/value - Extending the findings of the European Commission report (2015c) by examining how well medical tourists are informed about the decision they are making, would be of perceived value. These are important indicators at European level by helping each Member State to measure its medical tourism services.

Keywords Data envelopment analysis (DEA), Efficiency, Health and medical tourism,

Cross-border health care

Paper type Research paper

\section{Introduction}

In June 2010, the European Commission adopted the Communication, "Europe, the world's No. 1 tourist destination - a new political framework for tourism in Europe". This communication set out a new strategy and action plan for EU tourism. Tourism has a wide-ranging impact on growth, employment and social development in the EU. The

(C) Lorena Androutsou and Theodore Metaxas. Published in Journal of Tourism Analysis: Revista de de Análisis Turístico. Published by Emerald Publishing Limited. This article is published under the Creative Commons Attribution (CC BY 4.0) licence. Anyone may reproduce, distribute, translate and create derivative works of this article (for both commercial and non-commercial purposes), subject to full attribution to the original publication and authors. The full terms of this licence may be seen at http://creativecommons.org/licences/by/4.0/legalcode

The authors would like to express special thanks to Dr Kotsopoulos Nikolaos for providing insight and expertise that greatly assisted this research. His assistance and contribution to the methodology and his esteemed guidance to the modelling was of great importance.
Efficiency of medical tourism industry

Received 13 February 2019 Revised 14 May 2019 12 June 2019 Accepted 24 June 2019 
inbound tourism is contributing $€ 356$ billion in annual revenue to the European Economy (European Commission, 2017a). Health tourism in the EU is still a largely understudied and undocumented field in academic and professional literature (European Parliament, 2017). Moreover, health tourism contends with both national and European legislation, which generates issues with equal access to healthcare and wellness (European Parliament, 2017). Connell (2013, p. 11) found that "surprisingly little is known about cross-border mobility, even in Europe, despite its considerable and regulated significance".

Cross-border care often refers to short and long term visitors to another EU country who find that they have to seek health care when they are abroad. These two classifications include those who fall ill when abroad and those who go abroad for planned treatment (WHO, 2014). Temporary visitors abroad include individuals traveling for work and for leisure (WHO, 2014). According to WHO (2014) temporary visitors are those who have travelled abroad for work and for leisure, and cross border health can be for them the most accessible or appropriate care. There has been a considerable increase in the volume of tourism in Europe, with especially large numbers traveling from northern to southern Europe in summer (Patterson, 2006). Medical tourism refers to people traveling to a country other than their own to obtain medical treatment (Horowitz et al., 2007). Medical tourism will play a significant role in shaping the future of medical care globally, as it sits at the growing intersections of technology, economy, cultural and other global relations (Jenner, 2008).

Health has always been on the European agenda. Several factors make health policies and the health systems across the European Union increasingly interconnected:

- patients receive health care across the EU;

- health professionals work in different EU countries;

- higher expectations for health care; and

- new developments in health technologies (European Commission, 2017b).

The number of individuals choosing to travel across national borders or overseas to receive medical treatments has been on the rise (European Commission, 2014). Making cross-border health care for European Union (EU) citizens possible, the Directive 2011/ 24/EU makes it easier for EU citizens to get medical treatment in another EU Member State and ensure that at least some of the costs are reimbursed in their own country. However, the Directive emphasises that Member States retain responsibility for providing safe, high-quality care on their territory, and that care should be provided according to their own standards of quality and safety. Health system performance is key to achieving the maximum that could be expected given the level of resources. Countries need to measure how well the health systems achieve to manage the arrival of the non-resident patients seeking treatment. Measurement of performance requires an explicit framework defining the goals of a health system against which outcomes can be judged and performance quantified. Performance comparison efforts are still in their early stages and there are many challenges involved in the design and implementation of comparison schemes.

Cross-border health including medical tourism has become a simpler way to get treatment abroad; and for temporary visitors such as medical tourists, can be the most accessible or appropriate care. Little is known empirically regarding the efficiency of EU hospitals while managing non-resident patients including medical tourists.

This study aims to measure the efficiency of the 15 EU Member States hospitals while managing non-resident patients including medical tourists for the years 2010-2014. The objectives of the study are as follows: 
- to perform the literature review regarding medical tourism and cross border health;

- to gather available data from EU Member States for the years 2010-2014;

- to design and run DEA model to measure the efficiency of the EU hospitals while managing non-residents patients including medical tourists;

- to analyse the results and compare the efficiency scores;

- to provide discussion of the results; and

- to come up with conclusions and proposals.

Efficiency of medical tourism industry

\section{Cross border health}

The EU has a compendium of Directives dealing with health issues; with laws and Directives applying to the most crucial areas such as cross-border health including medical tourism. European Union's Treaty and its Charter of Fundamental Rights $(\mathrm{C} 364 / 1,2000)$ and the EU institutions are bound to principles that ensure a high level of health protection. These are the right to benefit from medical treatment; access to health care - preventive, diagnostic and curative treatment regardless of financial means, gender or nationality (European Commission, 2015a). The Directive 2011/24/EU on the application of patients' rights in cross-border health care came into force on 24 April 2011 and aims to provide all EU citizens with equal access to quality health care, responding to their specific needs (European Commission, 2015b). In 2014, the Communication on health systems shows that the Commission promotes cooperation at EU level with a view to strengthen effectiveness, increase accessibility and improve resilience of the national health systems in the EU (European Commission, 2014). In 2015, the European Commission released a report on the "Operation of Directive 2011/24/EU on the application of patients' rights in cross-border healthcare" (European Commission, 2015c).

Moreover, it has released two Eurobarometers; one on patients' rights in cross-border healthcare in the European Union (Eurobarometer 425, 2015) and one on the preferences of Europeans towards tourism (Eurobarometer 414, 2015).

The first Eurobarometer (2015/425) describes that as for the proportion of Europeans who reported that they actually received medical treatment in another Member State, there was a relatively small difference from one EU country to another. The findings show that in eight Member States, the percentage of people who used cross-border health care in another EU Member State at greater than 5 per cent were Luxembourg (LU) 16 per cent, 12 per cent Italy (IT) and 10 per cent in Hungary (HU). Other countries, which ranked above the average, were Romania (RO) (8 per cent), Portugal (PT) (7 per cent), Czech Republic (CZ) (7 per cent), Poland (PO) (7 per cent) and Ireland (IE) (6 per cent). The high rates observed in LU compared to other EU countries may be because its population is made up of many citizens from other Member States who are therefore more likely to seek healthcare abroad. For 27 per cent of the respondents, language was a major obstacle to receiving healthcare abroad, which could actually make them feel more vulnerable. In total, 23 per cent of respondents would want to know the waiting times for the treatment, they are looking for and the same proportion would want information on health-care providers (Eurobarometer, 2015/425).

The second Eurobarometer (2015/414) under study, showed that spending time in the sun or at the beach continues to be the main reason for going on holiday, and the second reason for going on holidays was health treatment with a response of one person in eight (13 per cent). Very high scores were observed in PT, Latvia (LV), Sweden (SE), Malta (MT), HU, and Slovakia (SK). It is worth mentioning that holidaymakers reported factors related to sports 
JTA

26,2

or health not as the main motive for their main vacation in 2010 (3 per cent) but as an important factor boosting their holidays' choice.

These two Eurobarometer showed that health problems within the medical tourism spectrum can be an opportunity for traveling and accessing quality health care treatments in another country.

In 2016, the European Commission released a study aiming to contribute to effective cross-border cooperation between EU-Member States by means of pooling resources for high-cost medical equipment investments (European Commission, 2016).

The aforementioned reports and Eurobarometer showed that the European Commission is putting a considerable effort into simplifying the process of traveling abroad and getting treatment.

\section{Medical tourism}

Health tourism is defined as "the organized travel outside one's local environment for the maintenance, enhancement or restoration of an individual's wellbeing in mind and body" (Carrera and Bridges, 2006). The health tourism includes all the situations related to people who choose to travel to a state other than the country of affiliation to receive health caremedical treatment (the person will be mainly dealing with scheduled treatment). The reason behind the decision to move, which has health implications, is to obtain a health service in a different state from that of their own health affiliation (provided by an institution and/or professional affiliated to a foreign NHS) (European Commission, 2018). According to the Turkish Ministry of Health and Department of Health Tourism categorised health tourism into - medical tourism, thermal tourism, elderly tourism and disabled tourism (Turkish Ministry of Health, 2012). A subset of this is medical tourism, which is "the organized travel outside one's natural healthcare jurisdiction for the enhancement or restoration of the individual's health through medical intervention" (Carrera and Bridges, 2006). Connell (2013) has defined medical tourism as: "the phenomenon of people travelling from their usual country of residence to another country with the expressed purpose of accessing medical treatment". In the past, this usually referred to those who travelled from lessdeveloped countries to major medical centres in highly developed countries for treatment unavailable at homes (Horowitz et al., 2007). Medical tourism is becoming increasingly popular, is driven by marketplace forces and occurs outside of the view and control of the organised health-care system (Horowitz et al., 2007). Medical tourism is one growing dimension of health-care globalisation, whereby consumers elect to travel across borders or to overseas destinations to receive their treatment (Lunt and Carrera, 2010). It is clear that medical tourism is a "new system" to meet health needs (Geitona and Sarantopoulos, 2015). There are some of the interrelationships between different areas of health and medical tourism, including wellness and wellbeing tourism, dental tourism, stem-cell tourism, transplant tourism, abortion tourism, and xeno-tourism. Key to defining these areas are the relationships to concepts of wellness and illness and the extent to which regulation encourages individuals to engage in cross-border purchase of health services and products (Hall, 2011). The concept of e-medical tourism can be also linked to health care systems (Sarantopoulos et al., 2014a).

At the international level, health tourism is an industry sustained by 617 million individuals with an annual growth of 3.9 per cent annually and worth US $\$ 513 \mathrm{bn}$ (Carrera and Bridges, 2006). The medical tourism industry is a fast-growing global niche market that generated $\$ 20$ billion in income for destinations around the world (Woo and Schwartz, 2014). Some estimates on medical tourism between countries are made by consultancies in the process of assessing the potential of the medical tourism business. They range from 
estimates based on Deloitte's 2008 report on medical tourism, quantifying the number of people traveling abroad for healthcare at 30 and 50 million each year (Keckley and Underwood, 2008). Also, according to the Global Wellness Tourism Economy (2013), medical tourism market is worth US\$50-60bn. The latest projection on medical tourism is estimated to be $\$ 100 \mathrm{bn}$ industry (Fetscherina and Stephano, 2016). There are several studies providing estimate on medical tourism growth, but they are based on US figures (Keckley and Underwood, 2008; Gan et al., 2011; Gan et al., 2012; Jacobs et al., 2013).

According to the calculations in the study, in 2014, the total size of the European market

Efficiency of medical tourism industry for health tourism was equal to 56 million domestic arrivals and 5.1 million international arrivals (from all over the world), for a total of 61.1 million arrivals. The total market of health tourism makes up for 4.3 per cent of all the EU arrivals, 5.8 per cent of the domestic ones and 1,1 per cent of international arrivals (European Commission, 2018). At European level, health tourism comprises around 5 per cent of general tourism in the EU28 and contributes approximately 0.3 per cent to the EU economy (European Parliament, 2017). Health tourism has a much higher domestic share than general tourism does. Increasing the share of health tourism may reduce tourism seasonality, improve sustainability and labour quality and may help to reduce health costs through prevention measures and decreased pharmaceutical consumption (European Parliament, 2017). Revenues generated by health tourism amounted to 12 billion euro in Europe, according to the data of the OCSP Observatory-SDA Bocconi (European Commission, 2018).

To provide reliable and accurate data on the flow of medical tourists is very hard as agreed by other authors because most of the records are held by private entities (Johnson and Garman, 2010; Turner, 2012; Lunt et al., 2012). Data collection, measures and studies of medical tourism all need to be greatly improved if countries are to assess better both the magnitude and potential health implications of this trade (Hopkins et al., 2010). Despite the increasing number of people, companies and countries involved in medical tourism, very little is known about the key drivers and how countries are perceived as medical tourism destinations. Studies have tried to estimate the costs and the benefits of medical tourism (Hanefeld et al., 2013; Beladi et al., 2015); to investigate the understanding of the factors that influence the travel intentions of medical tourists through its empirical investigation, and especially in its targeting of customers' value perception (Wang, 2012); to investigate the decision to engage in medical tourism (Runnels and Carrera, 2012); or to investigate tourist executives' opinions, aspects and beliefs in medical tourism and examine factors affecting their potential investments (Sarantopoulos et al., 2014b); and to explain the development, functioning, purposes and possible implications of cross-border contracting (Glinos et al., 2010). Other studies suggest and test a mechanism to assess the medical tourism providers, perceptions about the tourists, perceived important product attributes when selecting a medical tourism destination (Woo and Schwartz, 2014). In addition, research has been conducted to develop a model explaining international medical travellers' intention formation by considering the impact of quality, satisfaction, trust and price reasonableness (Han and Hyun, 2015) or to develop a model by introducing and explaining main elements of medical tourism such as types of medical tourists (Ko, 2011).

\section{Material and method}

Empirical data that would provide evidence on measuring the efficiency of hospitals while managing non-residents including medical tourists in the EU, by using DEA is very limited.

The non-parametric mathematical programming approach frequently goes by the name Data Envelopment Analysis or DEA for short, attributed to Charnes et al. (1978) who introduced it. This name derives from the features of the method which is piece-wise linear 
and literally envelops the production input-output set. DEA can easily handle multi inputoutput technologies and it can be applied to small data sets, given that there is a reasonable proportion between the number of input and output variables and the number of observations.

DEA analysis has been widely used in other economic sectors since 1957 by Farrell (1957) as organisations have struggled to improve productivity and efficiency. DEA has a long history with lots of important publications in measuring efficiency of hospitals and clinics (Caves et al., 1982; Lovell, 1996; Cook and Seiford, 2009; Charnes et al., 1978; Färe et al., 1994; Coelli et al., 2005; Coelli and Perelman, 1996; Hollingsworth et al., 1999; Färe et al., 1989; Halkos and Tzeremes, 2010; Ancarani et al., 2009; Maniadakis et al., 2007; Androutsou et al., 2011; Staat, 2006; Geitona et al., 2013; Pulina et al., 2010; Khushalani and Ozcan, 2017; Steinmann and Zweifel, 2003; Leleu et al., 2014; Samut and Cafr1, 2016; Moran and Jacobs, 2013; Linna et al., 2006; Varabyova and Schreyögg, 2013; Medina et al., 2013).

DEA method has been also used in tourism industry by measuring the performance of the hotels (Assaf and Agbola, 2011; Barros, 2006; Tingting and Liang, 2015; Wöber, 2008; Kao et al., 2011; Soysal-Kurt, 2017; Hu et al., 2014; Debata et al., 2013). Therefore, this method has been selected as it has been used in both sectors (health and tourism) to measure efficiency and provide reliable results.

Data were obtained from the Organisation of Economic Co-operation and Development (OECD) and the European Core Health Indicators (ECHI), which is collecting the data through Eurostat. Eurostat collects data on health-care activities and provides data on hospital discharges, including the hospital discharges of non-residents, and these include hospital discharges of in-patients and day care patients. The results were obtained by using "DEAP Version 2.1 for windows" by Coelli (1996). This study aims to measure the efficiency of the 15 EU Member States hospitals while managing non-resident patients including medical tourists for the years 2010-2014. The availability of data was the main selection criteria of the 15 EU Member States.

The computation of the EU hospitals' efficiency while managing non-resident patients including medical tourists has been explored by using the non-parametric mathematical programming approach - DEA. Efficiency measurement refers to technical efficiency (TE), which aims at the maximisation of outputs for a given level of inputs, or conversely the minimisation of input use for a given output level. In this study, an input-oriented measure has been performed to evaluate by how much quantities can be proportionally increased without changing the output quantities used (Banker et al., 1984; Charnes et al., 1978; Hollingsworth et al., 1999).

The formulation used to define efficiency in this study is described as follows. To characterise production technology related to the efficiency measurement, each clinic uses variable inputs $\chi=\left(\chi_{1}, \ldots, \chi_{\mathrm{N}}\right) \in \mathrm{R}^{\mathrm{N}}$ to produce variable outputs $\mathrm{y}=\left(\mathrm{y}_{1}, \ldots, \mathrm{y}_{\mathrm{M}}\right) \in \mathrm{R}^{\mathrm{M}}{ }_{+}$. The clinic inputs can be transformed into outputs using technology that can be described by $\mathrm{GR}=\{(\mathrm{x}, \mathrm{y}): \mathrm{x}$ can produce $\mathrm{y}\}$. Corresponding to the GR, there is a family of input sets $\mathrm{L}(\mathrm{y})=$ $\{\mathrm{x}(\mathrm{x}, \mathrm{y}) \in \mathrm{GR}\}, \mathrm{y} \in \mathrm{R}^{\mathrm{M}}$. Input sets are assumed to be closed and bounded above, and to satisfy strong disposability of inputs. The input sets contain isoquants Isoq $L(y)=\{x: x \in L$ (y), $\theta \mathrm{x} \in \mathrm{L}(\mathrm{y}), \theta \notin(0,1)\}, \mathrm{y} \in \mathrm{R}^{\mathrm{M}}+$. Also corresponding to the GR of the technology is a family of output sets $\mathrm{P}(\mathrm{x})=\{\mathrm{y}:(\mathrm{y}, \mathrm{x}) \in \mathrm{GR}\}, \mathrm{x} \in \mathrm{R}^{\mathrm{N}}+$. Output sets are assumed to be closed and bounded above, and to satisfy the properties of convexity and strong disposability of outputs. A Farrell radial measure of the technical efficiency of input vector $\mathrm{x}$ in the production of output vector $\mathrm{y}$ is given by: $\mathrm{TE}(\mathrm{x}, \mathrm{y})=\min \{\theta: \theta \mathrm{x} \in \mathrm{L}(\mathrm{y})\}$, where $\theta=1$ indicates radial technical efficiency and $\theta<1$ shows the degree of radial technical inefficiency. 
DEA efficiency scores at EU Member States are related to the relative efficiency of the services provided by each Member State or to inefficiencies related to the excessive and incorrect input utilisation. Fully efficient EU Member States per year are those, which score 1.00 and achieve the highest performance, 100 per cent efficiency scores. Inefficiency or minimum levels of performance refer to any regressed scores below 1.00 or below 100 per cent efficiency scores.

This study runs two (2) models to analyse the efficiency of the Member States health systems when treating non-resident patients. The reason of creating these two models is due to data availability. The study used all the data available per year and per reference country. The study used as output the indicator hospital discharges of non-residents, which includes hospital discharges of in-patients and day care patients. Medical tourists can be classified as a non-resident category of patients that have been discharged by the hospital after an episode of care.

The study considers hospitals as a multi-product organisation with the annual number of practising physicians and practising qualified nurses and midwives per 100,000 inhabitants per EU Member State used as labour inputs and the number of beds as an aggregate proxy of capital inputs. Table I shows the inputs and outputs used in the two models along with a description of the data used and the sources of the data. In both models, it used three (3) inputs (hospital beds, total number of practising physicians, per 100,000 inhabitants and practising qualified nurses and midwives, per 100,000 inhabitants).

The difference in the two models is that model nol (MA) used two outputs (hospital discharges in-patients per 100,000 inhabitants, number of non-resident people among all people discharged from hospital per 100,000 inhabitants), while model no. 2 (MB) used two outputs by keeping the same indicator "the number of non-resident people among all people discharged from hospital per 100,000 inhabitants", but as a second output indicator it used the day cases/number of outpatients. The indicator on patient mobility meets the increasingly important EU-health policy issue of cross-border care. Increased patient mobility raises a number of issues and concerns in Member States such as health care availability and utilisation, health infrastructure development, cost sharing and patient safety. Therefore, the main indicator taken into consideration in measuring the EU hospitals' efficiency while managing non-resident patients including medical tourists, is the number of non-resident people among all people discharged from hospital per 100,000 inhabitants. A non-resident patient is a patient living in another country/region but coming in the country/region of reference for treatment and/or care. Each EU Member State is considered as a single decision-making unit (DMU) in terms of provision of in-patient care and day cases/outpatients. The available data provided by more than one EU Member State per year was for the period 2010-2014; therefore, the DEA models were evaluated in terms of

Inputs and outputs

Model $1 \quad$ Model 2

Inputs

Hospital beds per 100,000 inhabitants

Total number of practising physicians per 100,000 inhabitants

Total number of practising qualified nurses and midwives, per 100,000 inhabitants

Outputs

Hospital discharges of inpatients per 100,000 inhabitants

Hospital discharges of non-resident inpatients per 100,000 inhabitants

Day cases/number of outpatients per 100,000 inhabitants
Efficiency of medical tourism industry

121

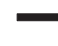


their cross-country performance over that period. The study used 49 DMUs for the aforementioned years.

The input-oriented method has been chosen due to the fact that the output used in this study -the non-resident people among all people being discharged - is a source which presents the arrival of medical visitors to the host Member State hospitals, which regarding to the usual health systems procedure is an indicator that in terms of budget and resources allocation cannot be predicted, but is aggregated to the number of "health care users". A hospital discharge is the formal release of a patient from a hospital after a procedure or course of treatment (episode of care) (ECHI, 2017). The inputs used; hospital beds and the human resources are indicators forming a health care system and can be crucial when planning a reform to achieve efficiency.

There are some methodological limitations that should be mentioned as the fact that the data available per year did not include the same countries. It is worth pointing out that the efficiency scores could vary if different models were to be run. Data availability in the EU on provision and utilisation rates of medical tourism is only limited. Institutional barriers such as European comparison of waiting times to enable patients to make informed choices when seeking medical care in another Member State, is very limited. The use of the output data provides information about the patients that are non-residence to the host country they received treatment, and these data include those that are medical tourists. However, the data available do not distinguish groups. Therefore, for the purposes of this study, it is assumed that medical tourists are included in the data of those received cross-border health, as they can lay in the category of temporary visitors that have travelled abroad for work and/or for leisure and cross-border care was for them the most accessible or appropriate care. To overcome these limitations data needs to be gathered from Member States at European level annually. This will facilitate future research and will provide comparable results that can form the basis for decision making.

To create comparable units and avoid heterogeneity of the sample the data used were from the EU Member States that have provided figures on the number of non-resident people among all people discharged from hospital per 100,000 inhabitants. In addition, future research would be benefited if the selection of data in EU, along with different trade blocs is homogeneous, so as future analysis can provide comparable results. Another important limitation refers to the fact that outputs adjusted for case-mix and in-patients' severity have not been taken into consideration due to the lack of relevant data. Consequently, the data set used dos not reflect output qualitative dimensions, which should constitute a primary criterion in the evaluation of hospital care. Moreover, TE has been used as an input-oriented measure but an output-oriented measure including patients' satisfaction of the services may be useful for long-term growth of the industry, as it is an important and commonly used indicator for measuring the quality in health care. It could also be useful to compare the findings of this study with other studies that have measured the efficiency of health systems in the sample countries, but this study has put emphasis on the non-resident patient discharges, which is a relatively new issue, and most of the available comparable studies have not used such a DEA output.

\section{Results}

In this paper, EU Member States performance has been assessed by measuring hospitals efficiency while managing non-resident patients including medical tourists, through a set of similar DMUs. The results at a European level by running Model No.1, showed that in 2010 all the countries with available data (HU, IE, LU)] were fully efficient when providing medical treatment to those that are non-residents. In 2011, six [HU, IE, LU, IT), Slovenia (SI), 
Lithuania (LT)] out of ten countries were fully efficient, while CZ and Croatia (HR)] had the lowest efficiency scores. In 2012, six [IE, LU, SI, MT, RO and SK] out of fourteen countries were fully efficient, while HR, CZ and Spain (ES) showed the lowest efficiency scores among the countries studied. In 2013, five (IE, LU, MT, RO, SI) out of 13 countries were fully efficient, while HR and Italy (IT) where those with the minimum levels of performance. In 2014, four (LU, SI, MT, RO) out of ten countries were fully efficient, while Germany (DE) showed the minimum level of performance. Overall, the countries under study were very efficient, as the ranking between the scores throughout the years was from the lowest 0.71 (HR) to the highest 1 (LU, IE, SI, RO and SK).

The results by running model no. 2 showed that in 2010, 2011 and 2012 two countries (IE, LU) out of three, ten and fourteen accordingly, were fully efficient. In 2013, three (IE, LU, MT) out of eleven countries scored 1. In 2014, four out of ten countries were fully efficient. Throughout the years, IE and LU were fully efficient, while HU, CZ, DE and LT achieved only the minimum levels of performance.

By comparing the two models, the results show that IE and LU were fully efficient run by both models throughout the years. The rest of the Member States run by Model 1 achieved better scores than run by Model 2, meaning that they could manage better in-patients than day cases/outpatients. The Member States with the broader differences in scores between the two models are HU, CZ, DE and LT. Figure 1 shows the results of the two models for the time horizon of the analysis.

\section{Discussion}

By considering the importance of the cross-border Directive 2011/24/EU that was engaged by the Member States in 2013, this study's observations were that the efficiency scores achieved per country were similar through the years before and after this milestone. The reason that there is no considerable efficiency improvement after 2013 can be due to the issue that the Directive was not properly disseminated to the citizens, as it was also
Efficiency of medical tourism industry

COMPARISON OF 2 effi ciency models 2010-2014

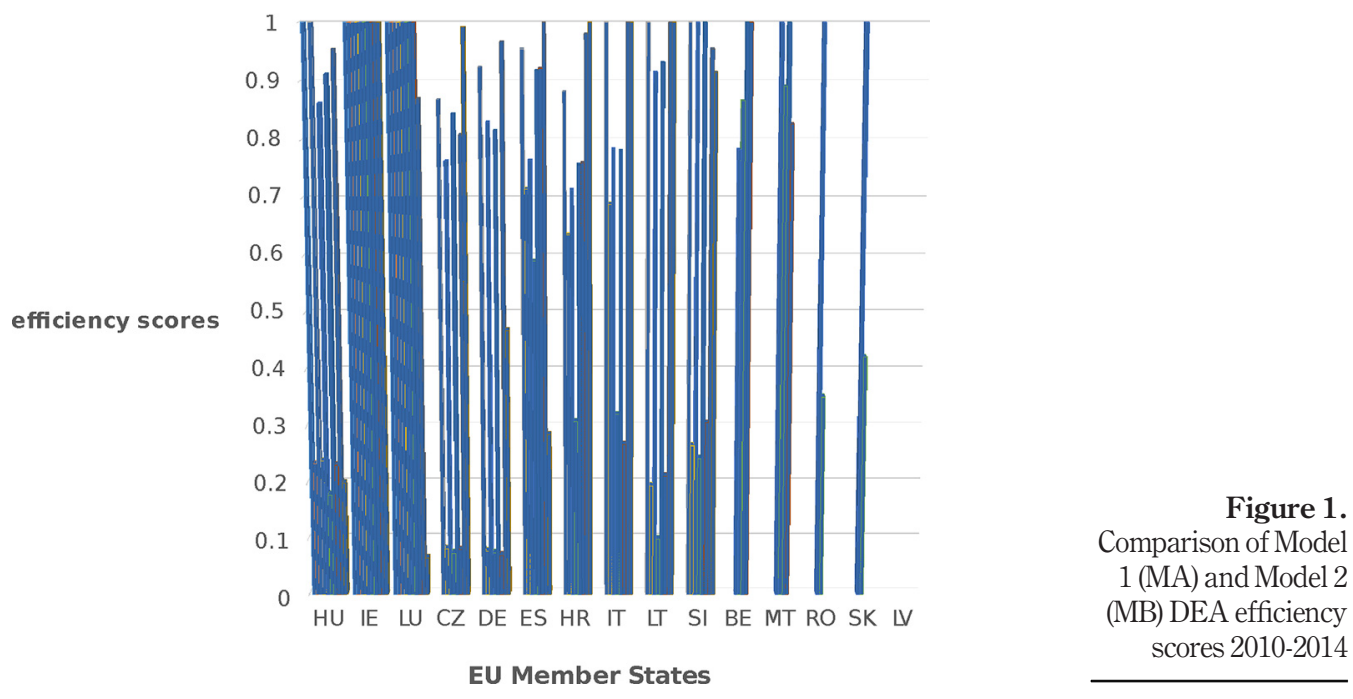


concluded by the report regarding the operation of European Commission (2015c) Directive. However, it is worth mentioning that after 2011 (the year that the Directive was published) more Member States were collecting data on non-residents patients. The Member States can link this to an observation that cross border health/medical tourism is gaining a great interest and an early stage collection of reliable data has been performed. The results also showed that LU and IE were fully efficient throughout the years of consideration. These results can be linked to the findings of the Eurobarometer 2015/425, which reported that the percentage of people who used cross-border healthcare in another EU Member State and was greater than 5 per cent was LU and IE. LU high performance can also be due to the facts highlighted at the same Eurobarometer, that was among the countries that were more open to cross-border healthcare and as an international country - with population made up of many citizens from other Member States and many people working in LU but living in neighbouring countries - may support a health system that needs to respond to nonresidents provision of health care on a daily basis, meaning that LU health system is more familiar with the cross-border health policy. Another factor, which was a major obstacle for respondents to travel, was the language. LU and IE may be fully efficient also due to the fact that health professionals in both countries speak fluent English. This encourages patients to use the health-care facilities, but also creates a level of understanding of the health care needs by the health professionals; which may lead to a more efficient health system. Addressing language barriers through interpreters and language training professionals is also important for the safety of mobile patients, but again, these measures have come to be seen as vital for all high-quality care due to the increasing ethnic heterogeneity of Europe (Legido-Quigley et al., 2007). By comparing this study's observations to the Eurobarometer 2015/414 results, the countries with the highest scores of the population that travelled due to health reason were PT, LV, MT, HU, SK; these countries were also very efficient in treating non-residents patients according to the findings of this study. However, the determining factor is whether the cost to the patient is seen as a barrier to free movement (LegidoQuigley et al., 2007).

\section{Conclusions}

Seeing the necessity for comparative assessment in the hospitals across the EU, this study comes at the right moment to carry out this research at an EU Member State level, as efficiency is particularly crucial in the context of defining new areas of potential national actions such as cross-border health/medical tourism. This study highlighted the fact that cross-border health and medical tourism can be interrelated concepts regarding the freedom to move to get the most accessible or appropriate medical treatment to any EU Member State within the defined procedures for reimbursement. The introduction of DEA as a practical research tool for examining efficiency across EU-Member States hospitals seems to open a path to evaluate and compare health system performance from a cross-border/ medical tourism perspective. The study presented that the efficiency of this market industry differs between EU Member States and the reasons are diverse and can be ascribed to lacking information, differences of national health systems, organisational and administrative hurdles and lacking political support.

Member States need to put more effort into improving and broadening data collection. This study proposes further analysis through field surveys at medical clinics, that will enable measurements regarding perceived quality, satisfaction and trust in the staff and clinic. Waiting times measurements aiming at EU and international comparisons would also benefit patients who seek cross-border alternatives for their care. 
The outcomes of such study would have significant associations affecting intentions to revisit clinics and the destination country. Extending the findings of the European Commission (2015c) report by examining how well medical tourists are informed about the decision they are making, would be of perceived value. These are important indicators to be considered at the European level and would help each Member State to measure its medical tourism services.

Health system performance comparisons have the potential to provide a "rich" source of evidence as well as to influence policy. Measuring its efficiencies at the regional, local or even clinical level aiming at offering high-quality health-care services that would encourage medical tourists to visit and/or revisit the countries, could potentially bring economic advantages for many EU-Member States. Studies like this can form the basis for policymakers interested in understanding whether their health system is performing as well as it could while treating patients from abroad - including medical tourists. Growth is a priority in Europe and the health systems should also aim for it by considering medical tourism as an incentive. The successful integration of European policies into a local system, and the endorsement of other Member States best practices, often involves a degree of adaptation to ensure compatibility with existing structures that may take time. Therefore, as the degree of adaption of the EU Directive 2011/24/EU is quite recent and aims to have a beneficial effect on health care systems, according to the results of this study it is worth to compliment the Member States for their performance so far. Further research at national, regional and European level that would provide evidence in developing and integrating health tourism and healthcare is needed. Coordinated and targeted funding actions on eliminating barriers to the economic growth of health tourism and that correspond to "open" health-care systems, should be introduced by policymaker.

\section{References}

Ancarani, A., Mauro, C.D. and Giammanco, M.D. (2009), "The impact of managerial and organizational aspects on hospital wards' efficiency: evidence from a case study", European Journal of Operational Research, Vol. 194 No. 1, pp. 280-293, available at: https://doi.org/10.1016/j. ejor.2007.11.046

Androutsou, L., Geitona, M. and Yfantopoulos, J. (2011), "Measuring efficiency and productivity across hospitals in the regional health authority of Thessaly in Greece", Journal of Health Management, Vol. 13 No. 2, pp. 121-140, available at: https://doi.org/10.1177/097206341101300201

Assaf, A.G. and Agbola, F.W. (2011), "Modelling the performance of Australian hotels: a DEA double bootstrap approach", Tourism Economics, Vol. 17 No. 1, pp. 73-89, available at: https://doi.org/ 10.5367/te.2011.0027

Banker, R.D., Charnes, A. and Cooper, W.W. (1984), "Some models for estimation of technical and scale efficiencies in data envelopment analysis", Management Science, Vol. 30 No. 9, pp. 1078-1092, available at: https://doi.org/10.1287/mnsc.30.9.1078

Barros, C.A.P. (2006), "The measurement of efficiency in Portuguese hotels using data envelopment analysis", Journal of Hospitality and Tourism Research, Vol. 30 No. 3, pp. 378-400, available at: https://doi.org/10.1177/1096348006286798

Beladi, H., Chao, C.C., Ee, M.S. and Hollas, D. (2015), "Medical tourism and health worker migration in developing countries", Economic Modelling, Vol. 46, pp. 391-396, available at: https://doi.org/ 10.1016/j.econmod.2014.12.045

C364/1 (2000), "Official journal of the European communities': chapter of fundamental rights of the European Union”, available at: www.europarl.europa.eu/charter/pdf/text_en.pdf (accessed 10 May 2019).
Efficiency of medical tourism industry 
Carrera, P.M. and Bridges, J.F. (2006), "Globalization and healthcare: understanding health and medical tourism", Expert Review of Pharmacoeconomics and Outcomes Research, Vol. 6 No. 4, pp. 447-454, available at: https://doi.org/10.1586/14737167.6.4.447

Caves, D.W., Christensen, L.R. and Diewert, W.E. (1982), "The economic theory of index numbers and measurement of input, output and productivity", Econometrica, Vol. 50 No. 6, pp. 1393-1414, available at: www.jstor.org/stable/1913388?seq=1\#page_scan_tab_contents

Charnes, A., Cooper, W.W. and Rhodes, E. (1978), "Measuring efficiency of decision-making units", European Journal of Operational Research, Vol. 2 No. 6, pp. 429-444, available at: https://doi.org/ 10.1016/0377-2217(78)90138-8

Coelli, T. (1996), “A guide to DEAP version 2.1: a data envelopment analysis (computer) program”, Centre for Efficiency and Productivity Analysis, University of New England. CEPA Working; Papers No.08/96. ISSN 1327-435X. ISBN 186389 4969; 96/08, available at: www.owlnet.rice.edu/ $\sim$ econ380/DEAP.PDF

Coelli, T. and Perelman, S. (1996), "Comparison of parametric and nonparametric distance functions: with application to European railways", CREPP Discussion paper, University of Liege, Liege, pp. 96-1011, available at: http://hdl.handle.net/2268/35665

Coelli, T., Rao, D.S.P. and O'Donell, Battase, G.E. (2005), An Introduction to Efficiency and Productivity Analysis, Springer, available at: http:/facweb.knowlton.ohio-state.edu/pviton/courses/crp394/ coelli_Intro_effic.pdf

Connell, J. (2013), "Contemporary medical tourism: conceptualisation, culture and commodification", Tourism Management, Vol. 34, pp. 1-13, available at: https://doi.org/10.1016/j.tourman.2012.05.009

Cook, W. and Seiford, L. (2009), "Data envelopment analysis (DEA) - thirty years on”, European Journal of Operational Research, Vol. 192 No. 1, pp. 1-17, available at: https://doi.org/10.1016/j. ejor.2008.01.032

Debata, B.R., Patnaik, B., Mahapatra, S.S. and Sreekumar, S. (2013), "Efficiency measurement amongst medical tourism service providers in India", International Journal for Responsible Tourism, Vol. 2, p. 1, available at: http://repec.turismulresponsabil.ro/RePEc/amfarchive/2013-1/2013-1-124-31.pdf

Eurobarometer 414 (2015), "Preferences of Europeans towards tourism", Conducted by TNS Political and Social at the request of the European Commission, Directorate-General for Internal Market, Industry, Entrepreneurship and SMEs, European Union, available at: http://ec.europa.eu/ commfrontoffice/publicopinion/flash/fl_414_en.pdf (accessed 10 May 2019).

Eurobarometer 425 (2015), "Patients' rights in cross-border healthcare in the European union", Conducted by TNS Opinion and Social at the request of the European Commission, DirectorateGeneral for Health and Consumers (SANCO), European Union, available at: http://ec.europa.eu/ commfrontoffice/publicopinion/archives/ebs/ebs_425_sum_en.pdf (accessed 10 May 2019).

European Commission (2014), "Impact of information on patients' choice within the context of the directive 2011/24/EU of the European parliament and of the council on the application of patients' rights in cross-border healthcare", Final Report, August 2014. PMID: 26068214.

European Commission (2015a), "European patients' rights day: 10 benefits the EU brings to patients", available at: https://ec.europa.eu/health/sites/health/files/patient_safety/docs/ 2015_eu_patients_factsheet_en.pdf (accessed 10 May 2019).

European Commission (2015b), "Cross-border healthcare report highlights advances and efforts at EU and national levels", Health and Food Safety, 3 September, available at: http://ec.europa.eu/dgs/ health_food-safety/dyna/enews/enews.cfm?al_id=1616 (accessed 10 May 2019).

European Commission (2015c), "Operation of directive 2011/24/EU on the application of patients' rights in cross-border healthcare", Report from the Commission to the European Parliament and the Council, COM(2015) 421 final, 4 September, available at: https://ec.europa.eu/health/sites/ health/files/cross_border_care/docs/2015_operation_report_dir201124eu_en.pdf (accessed 10 May 2019). 
European Commission (2016), "Study on better cross-border cooperation for high-cost capital investments in health", Directorate-General for Health and Food Safety Directorate B - Health systems, medical products and innovation Unit B.3 - Cross-border Healthcare, eHealth, November 2016, available at: https://ec.europa.eu/health/sites/health/files/cross_border_care/ docs/hci_frep_en.pdf (accessed 10 May 2019).

European Commission (2017a), "The EU tourism industry, internal market, industry entrepreneurship and SMEs", available at: https://ec.europa.eu/growth/sites/growth/files/infographic_tourism.jpg (accessed 10 May 2019).

Efficiency of medical tourism industry

European Commission (2017b), "DG health and food safety, public health, cross-border healthcare, policy", available at: http://ec.europa.eu/health/cross_border_care/policy_en (accessed 10 May 2018).

European Commission (2018), "Conceptual framework on health and tourism - an interregional point of view", available at: https:/ec.europa.eu/eip/ageing/sites/eipaha/files/news/ conceptual_framework_on_health_and_tourism_-_an_interregional_point_of_view_ 20112018.pdf (accessed 7 May 2019).

European Core Health Indicators (ECHI) (2017), "ECHI data tool”, available at: http://ec.europa.eu/ health/dyna/echi/datatool/index.cfm (accessed 10 May 2019).

European Parliament (2017), "Research for TRAN committee - health tourism in the EU: a general, investigation, DG for internal policies, policy department for structural and cohesion policies, transport and tourism", available at: www.europarl.europa.eu/RegData/etudes/STUD/2017/ 601985/IPOL_STU(2017)601985_EN.pdf (accessed 7 May 2019).

Färe, R., Grosskopf, S. and Lovell, C.A.K. (1994), Production Frontiers, Cambridge University Press, Cambridge, available at: http://citeseerx.ist.psu.edu/viewdoc/download?doi=10.1.1.197.873\&rep=rep1\&type=pdf

Färe, R., Grosskopf, S. and Valdmanis, V. (1989), "Capacity competition and efficiency in hospitals: a nonparametric approach", Journal of Productivity Analysis, Vol. 1, pp. 123-138, available at: https://doi.org/10.1007/BF00157792

Farrell, M.J. (1957), "The measurement of productive efficiency", Journal Royal Statistics Society, Vol. 120 No. 3, pp. 153-281.

Fetscherina, M. and Stephano, R.M. (2016), "The medical tourism index: scale development and validation”, Tourism Management, Vol. 52, pp. 539-556, available at: https://doi.org/10.1016/j. tourman.2015.08.010

Gan, L., Gan, F. and James, R. (2011), "Medical tourism facilitators: patterns of service differentiation", Journal of Vacation Marketing, Vol. 17 No. 3, available at: https://doi.org/10.1177/ 1356766711409181

Gan, L. Gan, F. and James, R. (2012), "Survey of consumers' perceptions toward medical tourism”, (Study), 6 March, available at: http://dx.doi.org/10.2139/ssrn.2194850

Geitona, M. and Sarantopoulos, I. (2015), "Medical tourism - investment in health and economy", Policy and Economy, Editor Papazisis.

Geitona, M., Androutsou, L. and Yfantopoulos, J. (2013), "Efficiency assessment across homogeneous specialty clinics in the region of Thessaly, Greece", The Open Public Health Journal, Vol. 6 No. 1, pp. 11-20, doi: 10.2174/1874944501306010011.

Glinos, I.A., Baeten, R. and Maarse, H. (2010), "Purchasing health services abroad: practices of crossborder contracting and patient mobility in six European countries", Health Policy, Vol. 95 Nos 2/ 3, pp. 103-112, doi: 10.1016/j.healthpol.2009.11.016.

Halkos, G. and Tzeremes, N. (2010), "A conditional non-parametric analysis for measuring the efficiency of regional public healthcare delivery", Health Policy, Vol. 103 No. 1, pp. 73-82, available at: http://dx.doi.org/10.1016/j.healthpol.2010.10.021

Hall, C.M. (2011), "Health and medical tourism: a kill or cure for global public health?", Tourism Review, Vol. 66 Nos 1/2, pp. 4-15, available at: https://doi.org/10.1108/16605371111127198 
Han, H. and Hyun, S.S. (2015), "Customer retention in the medical tourism industry: Impact of quality, satisfaction, trust, and price reasonableness", Tourism Management, Vol. 46, pp. 20-29, available at: https://doi.org/10.1016/j.tourman.2014.06.003

Hanefeld, J., Horsfall, D., Lunt, N. and Smith, R. (2013), "Medical tourism: a cost or benefit to the NHS?", PLoS One, Vol. 8 No. 10, available at: https://doi.org/10.1371/journal.pone.0070406

Hollingsworth, B., Dawson, P. and Maniadakis, N. (1999), "Efficiency measurement of health care: a review of non-parametric methods and applications", Health Care, Management Science, Vol. 2 No. 3, pp. 161-172, available at: https://doi.org/10.1023/A:1019087828488

Hopkins, L., Labonté, R., Runnels, V. and Packer, C. (2010), "Medical tourism today: What is the state of existing knowledge?", Journal of Public Health Policy, Vol. 31 No. 2, pp. 185-198, available at: https://doi.org/10.1057/jphp.2010.10

Horowitz, M.D., Rosensweig, J.A. and Jones, C.A. (2007), "Medical tourism: globalization of the healthcare marketplace", MedGenMed, Vol. 9No No. 4, pp. 33, available at: www.ncbi.nlm.nih. gov/pmc/articles/PMC2234298/

Hu, J.-L., Yeh, F.-Y. and Tsai, Y.-C. (2014), "Regional traffic and medical services and cost efficiency of international tourist hotels in Taiwan", International Business Research, Vol. 7 No. 10, available at: http://dx.doi.org/10.5539/ibr.v7n10p36

Jacobs, J.P., Horowitz, M.D., Mavroudis, C., Siegel, A. and Robert, M. (2013), "Sade, surgical tourism: the role of cardiothoracic surgery societies in evaluating international surgery centers", The Annals of Thoracic Surgery, Vol. 96 No. 1, pp. 8-14, available at: www.ncbi.nlm.nih.gov/pmc/articles/PMC3885903/

Jenner, E.A. (2008), “Unsettled borders of care: medical tourism as a new dimension in America's health care crisis, care for major health problems and population health concerns, impacts on patients, providers and policy", Research in the Sociology of Health Care, pp. 235-249, available at: www. emeraldinsight.com/doi/pdfplus/10.1016/S0275-4959\%2808\%2926011-4

Johnson, T.J. and Garman, A.N. (2010), "Impact of medical travel on imports and exports of medical services”, Health Policy, Vol. 98 Nos 2/3, pp. 171-177, doi: 10.1016/j.healthpol.2010.06.006.

Kao, M.C., Lin, C.Y., Lai, M.C. and Huang, H.C. (2011), "Exploring the efficiency of international tourism development in an emerging market", African Journal of Business Management, Vol. 5 No. 17, pp. 7526-7532, available at: https://doi.org/10.5897/AJBM11.581

Keckley, P.H. and Underwood, (2008), "Medical tourism: consumers in search of value is Deloitte's report", available at: www.globalwellnesssummit.com/wp-content/uploads/Industry-Research/ Americas/2008-deloitte-medical-tourism-consumers.pdf

Khushalani, J. and Ozcan, Y.A. (2017), "Are hospitals producing quality care efficiently? An analysis using dynamic network data envelopment analysis (DEA)", Socio-Economic Planning Sciences, Vol. 60, pp. 15-23, available at: https://doi.org/10.1016/j.seps.2017.01.009

Ko, T.G. (2011), "Medical tourism system model", International Journal of Tourism Sciences, Vol. 11 No. 1, pp. 17-51, available at: https://doi.org/10.1080/15980634.2011.11434634

Legido-Quigley, H., Glinos, I., Baeten, R. and McKee, M. (2007), "Patient mobility in the european union”, BMJ, Vol. 334 No. 7586, pp. 188-190, available at: http://researchonline.lshtm.ac.uk/ 10426/1/188.full \% 20\%281\%29.pdf

Leleu, H., Moises, J. and Valdmanis, V.G. (2014), "How do payer mix and technical inefficiency affect hospital profit? A weighted DEA approach”, Operations Research for Health Care, Vol. 3 No. 4, pp. 231-237, available at: https://doi.org/10.1016/j.orhc.2014.06.002

Linna, M., Häkkinen, U. and Magnussen, J. (2006), “Comparing hospital cost efficiency between Norway and Finland”, Health Policy, Vol. 77 No. 3, pp. 268-278, available at: http://dx.doi.org/10.1016/j. healthpol.2005.07.019

Lovell, C.A.K. (1996), "Applying efficiency measurement techniques to the measurement of productivity”, Journal of Productive Analysis, Vol. 7 Nos 2/3, pp. 329-340, available at: https://doi. org/10.1007/BF00157047 
Lunt, N. and Carrera, P. (2010), "Medical tourism: assessing the evidence on treatment abroad", Maturitas, Vol. 66 No. 1, pp. 27-32, available at: https://doi.org/10.1016/j.maturitas.2010.01.017

Lunt, N. Smith, R. Exworthy, M. Green, S.T. Horsfall, D. and Mannion, R. (2012), "Medical tourism: Treatments, markets and health system implications: a scoping review", $O E C D$, Directorate for Employment, Labour and Social Affairs, available at: www.oecd.org/els/health-systems/ 48723982.pdf

Maniadakis, N., Kotsopoulos, N., Prezerakos, P. and Yfantopoulos, J. (2007), "Measuring intra-hospital clinic efficiency and productivity: application to a Greek university general hospital", European Research Study, Vol. 11 Nos 1/2, pp. 95-110, available at: www.ersj.eu/repec/ers/papers/ 08_12_p8.pdf

Medina, E., Häkkinenb, U., Linna, M., Anthunc, K.S., Kittelsend, S.A.C. and Rehnberg, C. (2013), "International hospital productivity comparison: experiences from the Nordic countries", Health Policy, Vol. 112 Nos 1/2, pp. 80-87, available at: http://dx.doi.org/10.1016/j.healthpol.2013.02.004

Moran, V. and Jacobs, R. (2013), "An international comparison of efficiency of inpatient mental health care system”, Health Policy, Vol. 112 Nos 1/2, pp. 88-99, available at: http://dx.doi.org/10.1016/j. healthpol.2013.06.011

Patterson, I. (2006), "Growing older: tourism and leisure behaviour of older adults", Wallingford: CABI.

Pulina, M., Detotto, C. and Paba, A. (2010), "An investigation into the relationship between size and efficiency of the Italian hospitality sector: a window DEA approach", European Journal of Operational Research, Vol. 204 No. 3, pp. 613-620, available at: https://doi.org/10.1016/j. ejor.2009.11.006

Runnels, V. and Carrera, P.M. (2012), “Why do patients engage in medical tourism?”, Maturitas, Vol. 73 No. 4, pp. 300-304, available at: https://doi.org/10.1016/j.maturitas.2012.08.011

Samut, P. and Cafr1, R. (2016), "Analysis of the efficiency determinants of health systems in OECD countries by DEA and panel tobit”, Social Indicators Research, Vol. 129 No. 1, pp. 113-132, available at: https://doi.org/10.1007/s11205-015-1094-3

Sarantopoulos, I., Katsoni, V. and Geitona, M. (2014a), "Medical tourism and the role of e-medical tourism intermediaries in Greece", Tourismos: An International Multidisciplinaty Journal of Tourism, Vol. 9 No. 2, pp. 129-145, available at: http://journaldatabase.info/journal/issn17908418

Sarantopoulos, I., Katsoni, V. and Geitona, M. (2014b), "A supply side investigation of medical tourism and ICT use in Greece", Procedia - Social and Behavioral Sciences, Vol. 148, pp. 370 -377, available at: https://doi.org/10.1016/j.sbspro.2014.07.055

Soysal-Kurt, H. (2017), "Measuring tourism efficiency of European countries by using data envelopment analysis", European Scientific Journal, Vol. 13 No. 10, available at: https:// eujournal.org/index.php/esj/article/view/9141

Staat, M. (2006), "Efficiency of hospitals on Germany: a DEA-bootstrap approach", Applied Economics, Vol. 5 No. 19, pp. 2255-2263, available at: https://hal.archives-ouvertes.fr/hal-00581903/document

Steinmann, L. and Zweifel, P. (2003), "On the (in)efficiency of Swiss hospitals", Applied Economics, Vol. 35 No. 3, pp. 361-370, available at: https://doi.org/10.1080/00036840210167183

The Global Wellness Tourism Economy (2013), "Report”, available at: www.globalwellnesssummit. com/images/stories/pdf/wellness_tourism_economy_exec_sum_final_10022013.pdf (accessed 10 May 2018).

Tingting, Y. and Liang, M. (2015), "Evolutional model of tourism efficiency based on the DEA method: a case study of cities in Guangdong province, China”, Asia Pacific Journal of Tourism Research, Vol. 20, pp. 789-806, available at: https://doi.org/10.1080/10941665.2014.932294

Turkish Ministry of Health (2012), "Evaluation report on medical tourism in Turkey 2012", Prepared by: Mehmet Barca, Erdal Akdeve, øklim Gedik Balay, ørfan ùencan, and Dursun AydÕn, Republic of Turkey Ministry of Health Directorate General of Health Services Department of

Efficiency of medical tourism industry 
Health Tourism, Opus Printing LLC. Found in Esma Gültüvin Gür Omay and Emrah Cengiz (2013), Health tourism in turkey: opportunities and threats, Mediterranean Journal of Social Sciences, MCSER Publishing, Rome-Italy Vol. 4 No.10, doi:10.5901/mjss.2013.v4n10p424.

Turner, L. (2012), "Beyond 'medical tourism': Canadian companies marketing medical travel", Globalization and Health, Vol. 8 No. 1, p. 16, available at: https://doi.org/10.1186/1744-8603-8-16

Varabyova, Y. and Schreyögg, J. (2013), "International comparisons of the technical efficiency of the hospital sector: panel data analysis of OECD countries using parametric and non-parametric approaches", Health Policy, Vol. 112 Nos 1/2, pp. 70-79, available at: http://dx.doi.org/10.1016/j. healthpol.2013.03.003

Wang, H. (2012), "Value as a medical tourism driver", Managing Service Quality: An International Journal, Vol. 22 No. 5, pp. 465-491, available at: https://doi.org/10.1108/09604521211281387

WHO (2014), Footman, K., Knai, C., Baeten, R., Glonti, K., McKee, M., Cross-border health care in Europe, Policy Summary 14, available at: www.euro.who.int/_data/assets/pdf_file/0009/ 263538/Cross-border-health-care-in-Europe-Eng.pdf (accessed 10 May 2018).

Wöber, K.W. (2008), "Data envelopment analysis (DEA) to the field of travel and tourism", Journal of Travel and Tourism Marketing, Vol. 21 No. 4, pp. 91-108, available at: https://doi.org/10.1300/ J073v21n04_07

Woo, E. and Schwartz, Z. (2014), "Towards assessing the knowledge gap in medical tourism”, Journal of Quality Assurance in Hospitality and Tourism, Vol. 15 No. 2, pp. 213-226, available at: https:// doi.org/10.1080/1528008X.2014.889516

\title{
Further reading
}

European Commission (2011), "Directive 2011/24/EU of the European parliament and of the council, on the application of patients' rights in cross-border healthcare", Official Journal of the European Union, 9 March, available at: http://eur-lex.europa.eu/LexUriServ/LexUriServ.do?uri=OJ:L:2011: 088:0045:0065:EN:PDF (accessed 10 May 2019).

\begin{abstract}
About the authors
Lorena Androutsou is a post doc Research Fellow at the Economics Department, at the University of Thessaly. She has received with Honours her $\mathrm{PhD}$ on Economics - graduated from the same university. She has fulfilled her postgraduate studies in London, doing two Master degrees at City University (Contemporary health and social care policy) and at Imperial College - Tanaka Business School (Health management). She was working for the European Commission for the DG Health and Food Safety, in the Health Determinants Unit (SANTE C4) for the public health field. She has 15 publications in national and international journals and 4 chapters in books, and she has been contributor in the European Commission's publications reports and projects. She has actively participated in 41 conferences. She is running her own course - teaching health policy at the postgraduate degree entitled "primary care" at the Medical school of Thessaly in Greece.

Theodore Metaxas is an Associate Professor of Economic Development, Department of Economics, University of Thessaly, Volos, Greece. His research interests' concern urban development and territorial competition, business competitiveness, strategic planning and urban management, tourism development policies and planning, place marketing, especially in the area of South and Eastern Europe. He has published in high-qualified journals such as Economics of Governance, Journal of Developing Areas, Defence and Peach Economics, Business History, European Planning Studies and Resources Policy. Theodore Metaxas is the corresponding author and can be contacted at: metaxas@uth.gr
\end{abstract}

For instructions on how to order reprints of this article, please visit our website: www.emeraldgrouppublishing.com/licensing/reprints.htm Or contact us for further details: permissions@emeraldinsight.com 